\title{
Management of production processes in the construction of logistics complexes
}

\author{
Boldyrieva L. M. ${ }^{1[0000-0002-9147-5524]}$, Kraus K. M.2[0000-0003-4910-8330] \\ and Stanislavyk O. V.3[0000-0003-2481-9961] \\ ${ }^{1}$ Poltava National Technical Yuri Kondratyuk University, Poltava, Ukraine \\ ${ }^{2}$ Borys Grinchenko Kyiv University, Kyiv, Ukraine \\ ${ }^{3}$ Odessa National Polytechnic University, Odessa, Ukraine \\ ${ }^{1}$ Boldyrewaljuda@ukr.net
}

\begin{abstract}
It is proved that a mandatory infrastructure elementfor international transport corridors, as well as for any large enterprise, is the availability of logistics complexes (warehouse). The expediency construction of logistics complexes with the help of modern metal structures and sandwich panels has been proved. The concepts of "logistics complex", "distribution center" and "logistics center" are analyzed. Classification of logistics centers by functional purpose and types of the most popular fast-growing logistics complexes by classes are given. Types of production processes in construction (design with the latest standards; professional approach combined with years of experience and availability of advanced construction technologies, modern equipment and advanced equipment; warranty obligations; free consultations) with management functions are characterized. It is substantiated project management system for the construction of logistics complexes, which takes into account the management functions (planning, organization, motivation, control) and includes such estimation indicators as construction costs and optimal location of the complex (by the criterion of minimum logistics costs). The logistics complex is characterized by following criteria: main purpose; localization factor; warehouse processing conditions of inventories; stored goods; degree of ownership. It is suggested to calculate the optimal localization of logistics complex using the coordinate method.
\end{abstract}

Keywords: construction, logistics, logistic systems, design, processes, technologies, management, functions.

\section{Introduction}

A mandatory infrastructure element for international transport corridors, as well as for any large enterprise, is the availability of logistics complexes (warehouse). Therefore, at the stage of production optimization and commercial activity it is necessary to effectively resolve the issue of design and construction of modern logistics complexes. Due to the systematic approach to the construction of logistics complex, while observing all the necessary design standards, it is possible to minimize the costs of logistics.

The realities of time require from construction contractors to build high-speed industrial, material and technical facilitiesin the shortest possible time with metal structures and sandwich panels that have high quality and low metal consumption. The construction of logistic complexes with the help of modern metal structures and sandwich panels. The construction of logistic complexes with the help of modern 
metal structures and sandwich panels is an effective solution both technically and economically.Such modern technologies satisfy needs in time and space, in particular in the plane of following criteria: speed, quality, reliability, availability and low cost (cost depends on the parameters: type and dimensions of logistics complex, design, volume of additional works). Many domestic companies attract additional external sources of financing for the construction of their own logistics complexes, usually foreign capital or its share.

The analysis displays that logistics complexes in Ukraine for different industries have not yet been formed. The active construction of logistics centers will contribute to the improvement of national, regional and transnational transport and logistics systems, as well as to the development of the economy both the economies of individual regions and the country as a whole.

Transport and logistics systems, in turn, will provide effective research, production, supply and transportation communications between economic agents. However, such infrastructure projects as construction of logistics centers are accompanied by a large amount of investment. For example, in developed countries, such investments account for 3-3.5 \% of annual GDP growth. For Ukraine, it is necessary to implement projects on the organization of logistics complexes at the intersection of transport routes of ethnic importance, connecting the North with the South, West with the East.

\section{An overview of the latest sources of research and publications}

Following foreign scientists have considered the issues of construction logistics: Susanna Hedborg Bengtsson. She studied Coordinated construction logistics. This topic is extremely popular and is widely discussed in the Swedish construction industry. To improve transport efficiency, Swiss are proposing to reduce the amount of resources used and to ensure workplace health and safety coordination [1]. C. Leifgen and S. Kujajewskias are convinced that the construction logistics system should be focused on the planning, control and monitoring functions, as this will ensure a high level of flow of resources and people at the construction site.

Logistics system in construction should also cover repository management and facility planning, enabling it to be more systematic and complete. The stages of a construction project, where its planning and implementation takes place, differ significantly in specific conditions: depending on the complexity of the project, stakeholder involvement or the volume of the construction project [2].

American Society of Civil Engineers (2014) Stakeholders can positively assist or hinder attempts at innovation. Much depends on the nature of their engagement. The stakeholder engagement process can be complex and unpredictable, more so if no strategic plan is put in place or if no systematic thinking is invested in the innovation. Stakeholder engagement in innovation process in general and innovation diffusion in particular is examined in the context of construction.

From a theoretical perspective, analysis of the effect of stakeholders could be expected to help in refining innovation process so that it produces decisions and outcomes more likely to lead to successful innovation and diffusion. To cover diverse applications from product development to the drafting and implementation of national standards, 19 innovation projects were studied. Accordingly, an explicit plan for communication 
and engagement with identified key stakeholders is necessary as a condition for successful innovation and diffusion [3].

The purpose of the study should be to identify and classify supply chain management (SCM) problems, and to clarify their causes during the construction, supply chain or at the intersection between these processes. This allows for identification of how on-site problems affect SCM in construction projects and how they can be mitigated [4].

The result of the research should be, first, the accumulation of theoretical knowledge (based on the theory of industrial networks), and secondly, the improvement of logistics in practice directly by a specialist [5]. However, this requires adjusting logistics off-site.

Customer satisfaction and continuous improvement are the main goals of construction logistics. Many researchers focus on relationships between contractors and end customers in order to improve understanding of the importance of customer satisfaction. However, the purpose of the study is to extend the logistics framework for building materials to satisfy the customer from owner to project manager level [6].

Problems of construction of logistic complexes in the territory of Ukraine are hardly considered in literary sources.Mostly in scientific and literary sources: firstly, problems faced by logistics at regional, national and international levels are highlighted; secondly, the issues of warehousing logistics process are analyzed; third, the classification of logistics centers by functional purpose, warehouses and warehouse networks, the typology of warehouse buildings.In particular, the "Program for the Development of National Network of International Transport Corridors in Ukraine" is listed as one of the ways of solving problems of creation of transport and warehouse logistics centers [7].

Some literature references point to the existence of logistics complexes in Ukraine that fulfill certain logistic functions. Most of them are concentrated in Kyiv and Odessa regions, in the East of the country. The purpose of research is to study the management of production processes in the construction of logistics complexes and to develop practical recommendations for its improvement.

The theoretical and methodological basis of scientific research is the dialectical method of scientific cognition, systematic approach to the study of economic phenomena, the provisions of modern economic theory, scientific works of scientistseconomists who deal with and deal with problematic issues of design activities in construction and logistics, recommendations of research institutions problems.

Scientific research is based on the use of general scientific methods of research: theoretical generalization, system analysis and synthesis; terminological analysis; abstraction and formalization.

\section{Main Body}

Historically, Ukraine has geographical borders with 7 countries (Belarus, Moldova, Poland, Russia, Romania, Slovakia, Hungary).Therefore, the expediency of forming international logistics complexes is a kind of platform in the trade between the CIS countries, Europe, Asia and the Caucasus.Thus, there are three pan-European transport corridors (ITC № 3, 5, 9) and five OGS corridors (№ 3, 5, 7, 8, 9) operating in Ukraine.Transportation on the MTK TRACECA (Europe - Caucasus - Asia) is 
developing [8]. According to research by the English Rendall Institute, Ukraine's transit potential is the highest in Europe and is 3.11 points [9]. In economically developed countries, companies form their own logistics facilities or use the services they provide.

It is advisable to locate logistics complexes in such cities of Ukraine as: Izmail, Kyiv, Lviv, Odessa, Uzhgorod/Chop, Kharkiv, Chernivtsi, Sarny (Rivne region), which are located near customs posts, railways and highways of regional and international importance, which are part of the MTC system, in particular in places with the highest density of turnover or transit.

Despite the large amount of scientific research in the field of logistics, logistics complexes are not separated into a separate category. The problem with identifying the logistics complex among other logistics objects arises from the interpretation of the concept of "logistics complex". In the scientific literature there are three concepts: "logistics complex", "distribution center" and "logistics center".

According to scientists, logistics centers are multimodal hubs aimed at improving efficient transportation, provide local concentration and implementation of various logistics tasks and functions (distribution, long-term storage and sale of goods and services) and integration of logistics systems, view macros infrastructure unit of logistics of region's economy. For example, Polish scientists interpret the concept of "logistics center" as a spatial object of defined functioning with a defined infrastructure and organization of activities, through which logistics services related to the reception, warehousing, distribution and dispatch of goods, as well as support services are implemented which may be provided independently by business entity to the sender or recipient" [10].

Domestic scientists in their works emphasize that the logistics center is a hub object of logistics networks, in which processes of distribution of cargo flows, change of vehicles, storage and inventory management. Also, scientists provide classification of logistics centers by functional purpose: international logistic distribution centers (economic area: 100-150 ha; radius of action: 500-800 km); regional logistics distribution centers (economic area: 20-50 ha; radius: 50-80 km); local logistic distribution centers (main task: completion of formation of modern distribution network system); branch logistics distribution centers (intended to serve a particular industry or entrepreneurs); logistics service centers [10].

Some scientists identify logistics centers with distribution centers and warehouses. In turn, the term "distribution center" is a warehouse complex that receives goods from manufacturing or wholesale companies located in other regions of the country or abroad and distributes them in smaller batches to customers (small and wholesale enterprises and retail) through their or their distribution network.

Logistics complexes are large-scale professional warehouses with auxiliary facilities (office buildings, service premises, security point, etc.). Unlike conventional warehouses, the logistics complexes include: super-easy storage of goods, simplified and as easy as possible moving them, reducing the time of their search, loading, sorting and shipment of goods, availability of modern hoisting and transport equipment, logistic service.

We believe that it is wrong to identify a logistics center and distribution or distribution centers. Characteristics of the logistics complex are given in Table 1. 
Table 1. Logistics complex characteristics

\begin{tabular}{|c|c|c|}
\hline \multirow{2}{*}{ Characteristic } & \multicolumn{2}{|c|}{ Logistics complex } \\
\cline { 2 - 3 } & Logistics center & Distribution center \\
\hline Main purpose & Consolidation / Deconsolidation & Stockpiling \\
\hline Localization factor & $\begin{array}{c}\text { Intersection of highways, integration } \\
\text { of different modes of transport }\end{array}$ & $\begin{array}{c}\text { Distribution type } \\
\text { (distribution centers) }\end{array}$ \\
\hline $\begin{array}{c}\text { Conditions of warehouse } \\
\text { processing of inventories }\end{array}$ & Transit transfer type & Special \\
\hline Stored goods & Universal & $\begin{array}{c}\text { Individual purpose } \\
\text { (corporate, contractual) }\end{array}$ \\
\hline Degree of ownership
\end{tabular}

The most popular high-speed logistics complexes are distinguished by following classes:

A - warehouses for responsible storage of any type of products by modern technologies (maximum permissible ceiling height is $10 \mathrm{~m}$, operation is calculated for a rather long period of time). For example, Roshen Corporation Logistics Center in Yagotyn [11] meets all the requirements for a Class A logistics facility;

$\mathrm{B}$ - an analogue of previous variant, but in a reduced proportion (most often it is a reconstruction or simplified model with a ceiling height of 6 to $8 \mathrm{~m}$ );

$\mathrm{C}$ - the building was reconstructed (a warehouse with limited premises);

D - underground and other unsuitable premises (for short-term storage of goods, archive).

Management of production processes in the construction of logistics complexes, first of all, provides for: designing according to the most up-to-date standards, ie at all stages of designing the development of complex projects (design, working design, working documentation); professional approach combined with years of experience and availability of advanced construction technologies, modern machinery and advanced equipment; guarantee obligations (guarantee of high quality of completed construction works, complete safety of structures); free consultations.

Managerial activity is important and involves combining different functions or activities. Management functions in construction can be called all the specialized types of various construction works and services. Term "function" is translated from Latin language and means "exercise, fulfillment". Main management functions include: planning and forecasting; organization, motivation, control.

Thus, each management function in construction is aimed at solving specific, diverse and complex problems of interaction between individual units, which require the implementation of large set of specific measures, in particular in the construction of logistics complexes.

When designing engineering networks (power and water supply systems, heating, ventilation and sewerage, special systems of video surveillance, access control, security and fire alarms, fire extinguishing, etc.), it is necessary to take into account the specificity and type of logistics complex. For example, designing:

- Refrigeration warehouses to ensure uninterrupted power supply in the system of warehouse equipment to ensure uninterrupted operation of refrigeration units;

- The composition of fuel and lubricants goods of chemical industry must take into account the safety requirements for storage of the relevant goods and materials.

The stage of preparation of a set of documents includes: 
- Design of premises for storage and distribution of products for retail chains, shops and supermarkets;

- Design of warehouse complexes for storage of goods or raw materials of industrial, economic and industrial enterprises;

- Designing of wholesale food warehouses, commodity bases, vegetables and granaries;

- Design of the rolling stock as part of large logistics complex, as well as a separate solution;

- Design of warehouses for goods with special requirements for storage conditions (pharmaceutical warehouses, warehouses of fuel and lubricants, warehouses of goods of the chemical industry, etc.).

Structurally and technologically designed logistics complex should include:

- Effectively located access areas and parking (taking into account the specific nature of the existing access roads by factors: the intensity of traffic, depending on the time of day and seasonality, etc.);

- Modern systems of automation of the accounting of goods, engineering systems and warehouse equipment for uninterrupted operation of logistic (warehouse) premises in the conditions of peak load;

- Rationally designed and placed areas of reception and unloading of warehouse products;

- Clear and clear scheme of placement of goods on the shelves inside the logistic (warehouse) premises;

- Reasonably planned and designed schemes for moving conveyors and loaders inside logistics (warehouse) premises.

The value of production cost of construction of distribution complex should be determined by formula (1):

(DMC + DLC + TC + VMC + FMC + TCI)

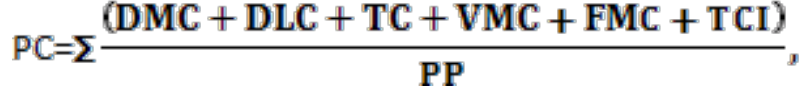

where $\mathrm{PC}$-production cost of construction, thousand UAH;

DMC - direct material costs, thousand UAH;

DLC- direct labor costs, thousand UAH;

$\mathrm{TC}$ - transport costs, thousand UAH;

VMC- variable material costs, thousand UAH;

FMC - fixed material costs, thousand UAH;

TCI- total capital investment in the construction of distribution complex, given by the factor of time, thousand UAH;

$\mathrm{PP}$ - payback period of construction (number of years).

It is possible to construct a graphical interpretation of the optimal localization of logistics complex using the coordinate method. To do this, you need to find the

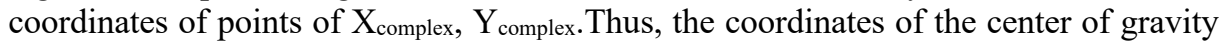
of cargo flows ( $\mathrm{X}_{\text {complex }}, \mathrm{Y}_{\text {complex }}$ ), ie the point at which logistics complex can be located, are given by formulas 2-3: 
where $M_{i}$ - material flow distributed to the $i$-consumer $(i=1,2, \ldots n)$;

$X_{i}, Y_{i}$ - coordinates of $i$-consumer $(i=1,2, \ldots n)$.

Therefore, in time, international corporations are in great demand for the individual design of logistics complexes of any size and complexity. Domestic builders, taking into account the wishes of customers, make architectural and construction sections of the project documentation strictly adhering to the requirements of current rules of design of logistics centers.

Types of production processes in construction, taking into account management functions are described in Table 2.

Table 2. Types of production processes in construction characteristics, taking into account management functions

\begin{tabular}{|c|c|}
\hline $\begin{array}{l}\text { Management } \\
\text { functions }\end{array}$ & Types of production processes in construction \\
\hline $\begin{array}{c}\text { Planning, } \\
\text { forecasting }\end{array}$ & $\begin{array}{l}\text { Designing (development of complex projects: project, working project, } \\
\text { working documentation); }\end{array}$ \\
\hline $\begin{array}{l}\text { Organization of } \\
\text { construction }\end{array}$ & $\begin{array}{l}\text { - Preparation of land for construction; } \\
\text { - Erection of foundation; } \\
\text { - Erection of the frame of building; } \\
\text { - Wall construction and erection; } \\
\text { - Installation of the facade of building; } \\
\text { - Roofing works; } \\
\text { - Connection of communications and engineering systems; } \\
\text { - Internal facing works; } \\
\text { - Installation of equipment and production systems; } \\
\text { - Arrangement of the adjacent territory (if necessary). }\end{array}$ \\
\hline $\begin{array}{l}\text { Customer } \\
\text { motivation }\end{array}$ & $\begin{array}{l}\text { - Guarantee of high quality of completed construction works; } \\
\text { - Full responsibility for the quality of work performed; } \\
\text { - Safety of structures; } \\
\text { - Guarantee of timely implementation and commissioning; } \\
\text { - Use of certified materials for construction; } \\
\text { - Free consultations; } \\
\text { - Implementation of projects in the shortest possible time. }\end{array}$ \\
\hline Control & Quality control at every stage of the project. \\
\hline
\end{tabular}

Scientific novelty is to justify project management system for the construction of logistics complexes, which takes into account management functions (planning, organization, motivation, control) and includes such estimated indicators as construction costs and the optimal location of complex (by the criterion of minimum logistics costs). Practical significance of scientific research results is to determine the relationship between the elements of production process management system in the logistics complexes construction; methodological approaches analysis and development an improved system of production processes management in the logistics complexes construction. 


\section{Conclusion}

Thus, in Ukraine, main reasons hampering the development of logistics complexes construction are following: insufficient demand for these objects, centralization of commodity, financial, management resources, the absence of large companies in the regions, the existence of outdated goods transportation scheme, significant financial costs, lack of investors, high capital intensity and high risks for long-term projects, lack of government policy and support in this area, lack of qualified specialists as problems with the purchase (lease) of land.

\section{References}

1. Susanna Hedborg Bengtsson (2019). Coordinated construction logistics: an innovation perspective. Construction Management and Economics. 2019.Volume 37, Issue 5.https://doi.org/10.1080/01446193.2018.1528372.

2. Leifgen Ch. and Kujajewski S. (2018). Integrated Digital and Model-Based Construction Logistics Management Based on Lean Thinking Approaches. The International Association for Automation and Robotics in Construction. pp. 428$435 \mathrm{https}$ ://doi.org/10.22260/ISARC2018/0060.

3. Widén K., Olander S. and Atkin B. (2014). Links between successful innovation diffusion and stakeholder engagement. Journal of management in engineering, Vol. 30. Issue 5.

4. Thunberg M., Rudberg M. and KarrbomGustavsson T. (2017). Categorising onsite problems: a supply chain management perspective on construction projects. Construction innovation, Vol. 17 № 1, pp.90-111. https://doi.org/10.1108/CI-102015-0059.

5. SundquistV., Gadde Lars-Erik and Hulthénk. (2018). Reorganizing construction logistics for improved performance. Journal of management in engineering, Vol. 36. Issue 1. pp. 49-65. https://doi.org/10.1080/01446193.2017.1356931.

6. Hyounseung Jang, Jeffrey S. Russell, and June Seong Yi (2003) A project manager's level of satisfaction in construction logistics. Can. J. Civ. Eng. Vol. 30. pp. 1133-1142.doi: 10.1139/L03-068.

7. Programa rozvitku natsIonalnoYi merezhI mIzhnarodnih transportnih koridorIv v UkraYinI (2006) / Postanova KabInetu MInIstrIv UkraYini vId 12 kvItnya 2006 r. № 496.https://zakon.rada.gov.ua/laws/show/496-2006-\%D0\%BF.

8. OfItsIyniy veb-sayt UkrzalIznitsI. http://www.uz.gov.ua.

9. Sidorchuk O.G. (2019) StrategIya sotsIalnoYi bezpeki UkraYini: poslIdovnIst formuvannya ta napryami realIzatsIYi. Problemi ekonomIki. 2019. №1. C. 176183. https://doi.org/10.32983/2222-0712-2019-1-176-183.

10. Krikavskiy E.V. (2008) Logisticheskiy tsentr - eto uzlovoy obekt logisticheskiy setey. Logistika: problemyi i resheniya. 2008. № 5 (18). C. 38-39.

11. OfItsIyniy veb-sayt korporatsIyi «ROSHEN». https://roshen.com/ua/uk/proroshen/logistychnyy-tsentr. 